\title{
Genital Tract Morphopathology of Red Sokoto and West African Dwarf Does in Makurdi
}

\author{
Ibrahim Garba1*, Philip Makama Dawuda', Iyorhemba Utim Ate'1, Jerry Ngutor Abenga² \\ ${ }^{1}$ Department of Theriogenology, College of Veterinary Medicine, Federal University of Agriculture Makurdi, Makurdi, \\ Nigeria \\ ${ }^{2}$ Department of Veterinary Pathology, College of Veterinary Medicine, Federal University of Agriculture Makurdi, Makurdi, \\ Nigeria \\ Email: *garbaibrahim16@yahoo.com
}

How to cite this paper: Garba, I., Dawuda, P.M., Ate, J.I. and Abenga, U.N. (2019) Genital Tract Morphopathology of Red Sokoto and West African Dwarf Does in Makurdi. Open Journal of Veterinary Medicine, 9, 21-44.

https://doi.org/10.4236/ojvm.2019.93003

Received: September 25, 2018

Accepted: March 26, 2019

Published: March 29, 2019

Copyright $\odot 2019$ by author(s) and Scientific Research Publishing Inc. This work is licensed under the Creative Commons Attribution International License (CC BY 4.0).

http://creativecommons.org/licenses/by/4.0/

\begin{abstract}
This study was conducted with the aim to record pathological conditions of the female genital tract of Red Sokoto (RS) and West African Dwarf (WAD) does with the objective of comparing the prevalence of genital tract pathology between the two breeds. Of the 211 (RS) and 221 (WAD) genital tract collected and examined, 104 (49.3\%) of RS and 97 (43.3\%) of WAD showed different types of pathological conditions. Highest occurrence of pathological conditions found in RS was in the uterus (38.4\%), followed by those in the ovary $(30.8 \%)$, cervix $(6.6 \%)$, salpinx $(6.2 \%)$ and vagina $(1.4 \%)$ while in $\mathrm{WAD}$, pathological conditions were highest in the uterus (28.1\%), and followed by ovary $(26.8 \%)$, salpinx $(5.0 \%)$, cervix $(2.2 \%)$ and vagina $(0.5 \%)$. In RS and WAD does, respectively, endometritis (11.9\% and 7.1\%) was the most common pathology followed by ovaro-bursal adhesion ( $10.4 \%$ and $5.4 \%$ ), inactive ovaries (4.3\% and $4.9 \%$ ), cystic Graffian follicles ( $4.2 \%$ and $2.2 \%$ ), paraovarian cyst (3.3\% and $3.1 \%$ ), uterine haemorrhage (3.8\% and $2.7 \%)$, and ovarian hypoplasia (2.4\% and $4.5 \%)$. Other pathological conditions found in RS and WAD does include cervical lesions: cervicitis (2.8\% and $1.8 \%$ ), haemorrhage (3.2\% and $0.5 \%)$; uterine lesions: hydrometra (1.9\% and $1.3 \%)$, pyometra $(2.8 \%$ and $1.8 \%)$, mucometra $(2.8 \%$ and $3.6 \%)$, metritis $(2.4 \%$ and $1.3 \%)$, post parturient metritis $(2.8 \%$ and $1.8 \%)$, caruncular atrophy $(1.4 \%$ and $0.5 \%)$, endometrial hyperplasia (1.0\% and $1.8 \%)$, melanosis $(1.9 \%$ and $1.8 \%)$, post parturient emphysematous metritis ( $1.4 \%$ and $2.2 \%)$, perimetritis (1.4\% and $2.2 \%)$, uterine congestion (1.9\% and $2.2 \%)$, oedema $(1.0 \%$ and $0.5 \%)$ and Cysticercus tenuicolis cyst (0.5\% and 0.5\%); esophageal lesions: salpingitis (1.9\% and 3.1\%), hydrosalpinx (1.0\% and $0.5 \%)$, tubo-bursal cyst (3.3\% and $0.9 \%)$, ovarian lesions: cystic corpora lutea ( $2.8 \%$ and $1.8 \%)$, oo-
\end{abstract}


phoritis (0.5\% and 1.8\%), and Cysticercus tenuicolis cyst (1.0\% and $0.9 \%)$. Hyperaemia $(0.5 \%)$ and calcification of cervical caudal rugae $(0.5 \%)$ occurred in RS only. Genital lesions were not statistically different $(\mathrm{P}>0.05)$ between RS and WAD does. In the two breeds, the 13 - 24 months age group had high prevalence of genital lesions. The current study has shown that endometritis and ovaro-bursal adhesions are the common female genital tract pathological conditions in Red Sokoto and West African Dwarf does. The high prevalence of female genital tract abnormalities may suggest that genital diseases are of serious limitation to goat production in Makurdi.

\section{Keywords}

Female Genital Tract, Prevalence, Morphopathology, Red Sokoto Doe, West African Dwarf Doe

\section{Introduction}

Goat keeping has assumed a key position in the rural development programmes of the developing countries especially Nigeria. This is because they contribute meat, milk, fibre, manure etc. that are useful to rural and semi-urban life. Small ruminants make up the bulk of the population of animals in Nigeria [1] and constitute about $63.9 \%$ of the total grazing domestic livestock [2] [3]. The 2011 National Agricultural Sample Survey indicated Nigeria has an estimated 72.5 million goats and 41.3 million sheep [4].

The demand for animal protein has been on the increase in Nigeria because of the increase in population over the years which have resulted into increased importation of meat and milk products to supplement the local shortfalls [5]. The average daily animal protein consumption per head in Nigeria was put at 15 g/day [6] with a further decline to $9.0 \mathrm{~g} /$ day [2] which is far less than the WHO recommendation of $35 \mathrm{~g} /$ day. Regular and successful reproduction is the key to profitable goat production. This entails early attainment of sexual maturity and raising of two crops of kids per year with a twinning rate of $10 \%-30 \%$ during a doe's reproductive life [7] [8]. This target may not be attained due to reproductive problems among female goats.

Genital tract abnormalities play an important role in animal production either by causing sub-fertility, infertility or sterility, longer inter-kidding interval, and increased expense on medication in farm resulting in huge economic loss to the livestock owners [9] [10] [11]. These disorders can be caused by congenital or hereditary, infectious, nutritional or environmental factors [9] [12].

The occurrence of genital pathologies has been reported to cause reproductive disturbances ranging from $1.9 \%$ to $23.32 \%$ in female goats [9] [11] [13] [14] [15]. The prevalence of genital pathologies has also been reported to increase with age in female goats [9] [16] and between breeds in cows [17].

Although reports on genital disorders in goats are scanty as compared to cattle 
and ewes, the information on the prevalence of female genital abnormalities may suggest the role of genital diseases in the limitation to goat production in order to improve their reproductive performance and proffer solutions. However, there is a paucity of information on the prevalence, causes and nature of pathological conditions of the genitalia of female goats especially the Red Sokoto and West African Dwarf does. Hence, the present study was undertaken to investigate abattoir specimens for the prevalence and types of genital tract morphopathologies in female goats.

\section{Materials and Methods}

\subsection{Study Location}

The study was carried out at the pathology laboratory of the veterinary teaching hospital annex, Federal University of Agriculture, Makurdi. Makurdi is located on the east central part of Nigeria on longitude $8^{\circ} 35^{\prime \prime} \mathrm{E}$ and latitude $7^{\circ} 44^{\prime \prime} \mathrm{N}$ and has a radius of $16 \mathrm{~km}$. The climate is tropical and the vegetation is predominantly guinea savannah with an annual rainfall of $1090 \mathrm{~mm}$. The area is defined by two seasons: the rainy season lasting from April to October and the dry season lasting from November to March with an average relative humidity of $26.3 \%$ to $71.3 \%$ throughout the year. The atmospheric temperature ranges from $27.38^{\circ} \mathrm{C}$ to $34.09^{\circ} \mathrm{C}[18]$.

\subsection{Sample Size}

Sample size was determined by using the formula of [19] at 95\% confidence level and prevalence rate of $15.14 \%$ as reported by [9] in Maradi Goats, Ibadan, Nigeria. Therefore, at least 200 non-pregnant genital tracts from Red Sokoto and West African Dwarf does, respectively, were collected.

\subsection{Source of Genital Organs}

Does genital organs sampled for the study were collected after the Halal slaughter procedure from Wurukum and international cattle market abattoirs, respectively, Makurdi, Benue State. Ethical approval for the research was obtained from the Faculty of Veterinary Medicine, Federal University of Agriculture, Makurdi and National Veterinary Research Institute (NVRI), vom.

\subsection{Sample Collection and Handling of Genital Organs of Does}

Samples were collected each for at least three days per week from March to September, 2016. Non-pregnant genitalia were used for the study. Age estimation was based on eruption and erosion of pair of incisor teeth pairs as described by [20]. The animals were grouped into four age groups of 6 to 12, 13 to 24,25 to 36 and $>36$ months respectively. Prevalence of genital abnormalities of the two breed and age groups of RS and WAD were recorded. The genital organs of does were collected after evisceration and placed into ice packed well labeled sterile containers then taken to the pathology laboratory, 
Veterinary Teaching Hospital, Annex, Federal University of Agriculture, Makurdi for examination.

\subsection{Gross Examination of Genital Organs of RS and WAD Does}

Systematic examination of the doe genital organs was carried out as described by [21]. Evaluation was done by visual appraisal, palpation and incision. Lesions were examined and described by their size, consistency, colour, shape, smell or location as described by [22] and the malformation of the different parts of the genital tracts were also observed and recorded. Each reproductive tract was opened by cutting with a pair of sterilized scissors, starting from the vulva, into the vagina through the cervix and uterine body, into each horn, oviduct and finally the ovaries.

Syringe and needle was used to aspirate fluid/pus into a graduated cylinder to measure the volume $(\mathrm{ml})$. Size, diameter and length of the abnormalities were measured using a meter rule $(\mathrm{mm})$. Follicles and corpus luteum $>12 \mathrm{~mm}$ were considered cystic [23].

\subsection{Preparation of Tissue Samples for Histological Examination}

The paraffin wax method described by [24] was used for processing tissue for histological examination. Representative samples were preserved in $10 \%$ formalin and processed after proper fixation to make paraffin embedded blocks in Spin tissue processor (STP), 120 Thermoscientific ${ }^{\circledR}$ at the National Veterinary Research Institute, Vom, Plateau State. Tissues were sectioned using a rotary microtome (MICROM HM340E) ThermoScientific ${ }^{\circledast}$ set at 4 micromes, picked onto slides and stained using H\&E stain method described by [25]. The processed slides were examined by light microscopy at various magnifications $(\times 4, \times 10$ and $\times 40)$. Pathological conditions in various parts of female genital tract were categorized based on characteristic gross as well histopathological features.

\subsection{Data Analysis}

Descriptive statistics were used to represent the data generated. Chi-square was used to compare association between the prevalence of lesion and breed. Odd ratio was determined to test the correlation between age and lesions.

Prevalence of abnormalities expressed in percentage was determined using the relationship:

$$
\text { Prevalence rate }(\%)=\frac{\text { Number of does affected }}{\text { Total number of does }} \times 100
$$

All data analysis was subjected to Graphpad Prism Statistical Software version 7.03 [26]. P-value was considered significant at $\mathrm{P}<0.05$.

\section{Results}

The prevalence of doe genital lesions of 104 (49.3\%) in Red Sokoto (RS) breed 
was higher as compared to 97 (43.3\%) prevalence in West African dwarf (WAD) breed (Table 1). There was no association between breed and prevalence of genital lesions.

Genital tract abnormalities with regard to age are shown in Table 2. The prevalence of genital lesions among age groups was found in the 13 - 24 months old in both breeds but higher in RS (25.6\%) as compared to that in WAD (17.0\%). There was no correlation in age and prevalence of genital lesions between RS and WAD does.

A total of 435 genital tracts of slaughtered does collected from the abattoir were examined of which $176(83.4 \%)$ of RS and $139(62.0 \%)$ of WAD exhibited various types of pathological conditions (Table 3 ). The pathological conditions were sometimes found as multiple lesions involving various parts of the same genital tract. The prevalence of pathological conditions found on the different parts of the genital tract samples collected were found to be highest in the uterus (38.4\%) and (28.1\%), followed by the ovary (30.8\%) and $(26.8 \%)$, cervix $(6.6 \%)$ and $(2.2 \%)$, oviduct (6.2\%) and (5.0\%) and vagina (1.4\%) and (0.5\%) in RS and WAD does, respectively. There was no significant difference $(\mathrm{P}>0.05)$ in the occurrence of pathologies on the different parts of the genital tracts examined between RS and WAD does, respectively.

The uterus exhibited the highest prevalence of diversity and frequency of lesions in both RS and WAD, however, the occurrence of uterine lesions was higher in RS (38.4\%) as compared to that of WAD (28.1\%). Various pathological conditions recorded in the uterus on the basis of gross and microscopic lesion are presented in Table 4. Endometritis had the highest occurrence among different lesions of the uterus viz: 25 (24\%) cases in RS does with prevalence rate of $11.9 \%$ and $16(16.5 \%)$ cases in WAD does with a prevalence rate of $7.2 \%$ (Table 4). Based on microscopic examination, endometritis in RS and WAD were classifies as chronic (Figure 1) (12.5\% and $10.3 \%)$, acute $(7.7 \%$ and $6.2 \%)$ and granulomatous endometritis (Figure 2) (3.9\% and 0.0\%) (Table 4). Hydrometra (Plate 3) (3.9\% and 3.1\%), pyometra (Figure 3, Figure 4) (5.8\% and 4.1\%), uterine hemorrhages $(7.7 \%$, and $6.2 \%)$, mucometra $(5.8 \%$ and $8.3 \%)$, post parturient metritis (5.8\% and $4.1 \%$ ), metritis (4.8\% and $3.1 \%$ ), uterine melanosis (Figure 5) (3.9\% and 2.1\%) and uterine congestions (3.9\% and 5.2\%) were frequently noticed in RS and WAD, respectively. Other uterine lesions found

Table 1. Prevalence of genital lesions in RS and WAD does.

\begin{tabular}{cccc}
\hline $\begin{array}{c}\text { Breed of } \\
\text { Doe }\end{array}$ & Number sampled & Number affected & $\begin{array}{c}\text { Prevalence } \\
\text { of lesions (\%) }\end{array}$ \\
\hline RS & 211 & 104 & $49.3^{\mathrm{a}}$ \\
WAD & 224 & 97 & $43.3^{\mathrm{a}}$ \\
& Total: 435 & 203 & 46.7 \\
\hline
\end{tabular}

RS $\left(P=0.8131, \chi^{2}=0.9508\right)$ and WAD $\left(P=0.3066, \chi^{2}=3.612\right)$. No significant difference $(P>0.05)$ between breed and prevalence of genital lesion. Figures with same superscript are not significantly different. 
Table 2. Age and prevalence of genital lesions in RS and WAD does.

\begin{tabular}{|c|c|c|c|c|}
\hline $\begin{array}{l}\text { Breed } \\
\text { of doe }\end{array}$ & $\begin{array}{c}\text { Age } \\
\text { (month) }\end{array}$ & Number sampled & Number affected & $\begin{array}{c}\text { Prevalence } \\
\text { of lesions (\%) }\end{array}$ \\
\hline \multirow[t]{5}{*}{ RS } & $6<12$ & 5 & $2(40.0 \%)$ & 0.95 \\
\hline & $13-24$ & 103 & $54(52.4 \%)$ & 25.6 \\
\hline & $25-36$ & 89 & $41(46.1 \%)$ & 19.4 \\
\hline & $>36$ & 14 & $7(50.0 \%)$ & 3.3 \\
\hline & Total & 211 & 104 & 49.3 \\
\hline \multirow[t]{5}{*}{ WAD } & $6<12$ & 19 & $8(42.1 \%)$ & 3.6 \\
\hline & $13-24$ & 90 & $38(42.2 \%)$ & 17.0 \\
\hline & $25-36$ & 75 & $38(50.7 \%)$ & 17.0 \\
\hline & $>36$ & 40 & $13(32.5 \%)$ & 5.8 \\
\hline & Total & 224 & 97 & 43.3 \\
\hline \multirow[t]{5}{*}{$\mathrm{RS}+\mathrm{WAD}$} & $6<12$ & 24 & $10(41.7 \%)$ & 2.3 \\
\hline & $13-24$ & 193 & $92(47.7 \%)$ & 21.2 \\
\hline & $25-36$ & 164 & $79(48.2 \%)$ & 18.2 \\
\hline & $>36$ & 54 & $20(37.0 \%)$ & 4.6 \\
\hline & Total & 435 & 201 & 46.2 \\
\hline
\end{tabular}

RS breed $\left(P=0.9252, \chi^{2}=0.471\right.$, odd ratio $\left.<1\right)$ and WAD breed $\left(P=0.3066, \chi^{2}=3.612\right.$, odd ratio $\left.<1\right)$. No statistical correlation in age and prevalence of genital lesions between RS and WAD does.

Table 3. Prevalence of pathologies on different parts of the genital tracts of RS and WAD does.

\begin{tabular}{|c|c|c|c|c|c|c|c|}
\hline \multirow{4}{*}{$\begin{array}{l}\text { Parts of } \\
\text { genital } \\
\text { organ }\end{array}$} & \multicolumn{4}{|c|}{ Breed } & \multirow{2}{*}{\multicolumn{2}{|c|}{$\begin{array}{c}\text { Prevalence of lesions } \\
(\%)\end{array}$}} & \multirow{3}{*}{$\begin{array}{c}\text { Overall prevalence } \\
\text { of lesions (\%) } \\
\begin{array}{c}(\mathrm{RS}+\mathrm{WAD}) \\
(\mathrm{n}=435)\end{array}\end{array}$} \\
\hline & \multicolumn{2}{|r|}{$\underline{\mathrm{RS}}$} & \multicolumn{2}{|c|}{ WAD } & & & \\
\hline & $\begin{array}{c}\text { Number of } \\
\text { lesions }\end{array}$ & $\begin{array}{l}\% \text { affected out } \\
\text { of } 104 \text { genital }\end{array}$ & $\begin{array}{c}\text { Number of } \\
\text { lesions }\end{array}$ & $\begin{array}{c}\% \text { affected } \\
\text { out of } 97 \text { genital }\end{array}$ & $\begin{array}{c}\text { RS } \\
(\mathrm{n}=211)\end{array}$ & $\begin{array}{c}\text { WAD } \\
(\mathrm{n}=224)\end{array}$ & \\
\hline & & lesion & & lesion & & & \\
\hline Ovary & 65 & 62.5 & 60 & 61.9 & 30.8 & 26.8 & 28.7 \\
\hline Oviduct & 13 & 12.6 & 10 & 10.3 & 6.2 & 5.0 & 5.3 \\
\hline Uterus & 81 & 78.0 & 63 & 65.0 & 38.4 & 28.1 & 33.1 \\
\hline Cervix & 14 & 13.5 & 5 & 5.2 & 6.6 & 2.2 & 4.4 \\
\hline Vagina & 3 & 2.9 & 1 & 1.0 & 1.4 & 0.5 & 0.9 \\
\hline & 176 & & 139 & & 83.4 & 62.0 & 72.4 \\
\hline
\end{tabular}

No significant difference $(\mathrm{P}>0.05)$ in the occurrence of pathologies on the different parts of the genital tracts between RS and WAD, respectively and for the two breeds.

include: endometrial hyperplasia (Figure 6), uterine oedema, post-paturient emphysematous metrtitis (Figure 7), perimetritis and Cysticercus tenuicollis cyst (Figure 8) were also found.

The prevalence of lesions in the ovary was higher in the RS does (30.6\%) as compared to WAD does (26.8\%) are shown in Table 5. The occurrence of 
Table 4. Prevalence of uterine lesions in RS and WAD does.

\begin{tabular}{|c|c|c|c|c|c|c|}
\hline \multirow{4}{*}{ Lesion } & \multicolumn{4}{|c|}{ Breed } & \multirow{2}{*}{\multicolumn{2}{|c|}{$\begin{array}{c}\text { Prevalence } \\
(\%)\end{array}$}} \\
\hline & \multicolumn{2}{|c|}{ RS } & \multicolumn{2}{|c|}{ WAD } & & \\
\hline & $\begin{array}{l}\text { Number } \\
\text { affected }\end{array}$ & $\begin{array}{c}\% \text { affected } \\
\text { out of } 104 \text { genital }\end{array}$ & $\begin{array}{l}\text { Number } \\
\text { affected }\end{array}$ & $\begin{array}{c}\% \text { affected } \\
\text { out of } 97 \text { genital }\end{array}$ & $\begin{array}{c}\text { RS } \\
(n=211)\end{array}$ & $\begin{array}{c}\text { WAD } \\
(n=224)\end{array}$ \\
\hline & & lesions & & lesions & & \\
\hline Uterine heamorrhage & 8 & 7.7 & 6 & 6.2 & 3.8 & 2.7 \\
\hline Chronic endometritis & 13 & 12.5 & 10 & 10.3 & 6.2 & 4.5 \\
\hline Acute endometritis & 8 & 7.7 & 6 & 6.2 & 3.8 & 2.7 \\
\hline Granulomatous endometritis & 4 & 3.9 & 0 & 0.0 & 1.9 & 0.0 \\
\hline Hydrometra & 4 & 3.9 & 3 & 3.1 & 1.9 & 1.3 \\
\hline Pyometra & 6 & 5.8 & 4 & 4.1 & 2.8 & 1.8 \\
\hline Mucometra & 6 & 5.8 & 8 & 8.3 & 2.8 & 3.6 \\
\hline Metritis & 5 & 4.8 & 3 & 3.1 & 2.4 & 1.3 \\
\hline Post parturient metritis & 6 & 5.8 & 4 & 4.1 & 2.8 & 1.8 \\
\hline Caruncular atrophy & 3 & 2.9 & 1 & 1.0 & 1.4 & 0.5 \\
\hline Endometrial hyperplasia & 2 & 1.9 & 4 & 4.1 & 1.0 & 1.8 \\
\hline Uterine melanosis & 4 & 3.9 & 2 & 2.1 & 1.9 & 1.0 \\
\hline $\begin{array}{c}\text { Post parturient } \\
\text { emphesematous-metritis }\end{array}$ & 2 & 1.9 & 1 & 1.0 & 1.0 & 0.5 \\
\hline Perimetritis & 3 & 2.9 & 5 & 5.2 & 1.4 & 2.2 \\
\hline Uterine congestion & 4 & 3.9 & 5 & 5.2 & 1.9 & 2.2 \\
\hline Cysticercus tenuicolis cyst & 1 & 1.0 & 1 & 1.0 & 0.5 & 0,5 \\
\hline Uterine oedema & 2 & 1.9 & 1 & 1.0 & 1.0 & 0.5 \\
\hline
\end{tabular}

No significant difference $(\mathrm{P}>0.05)$ in uterine lesions between RS and WAD.
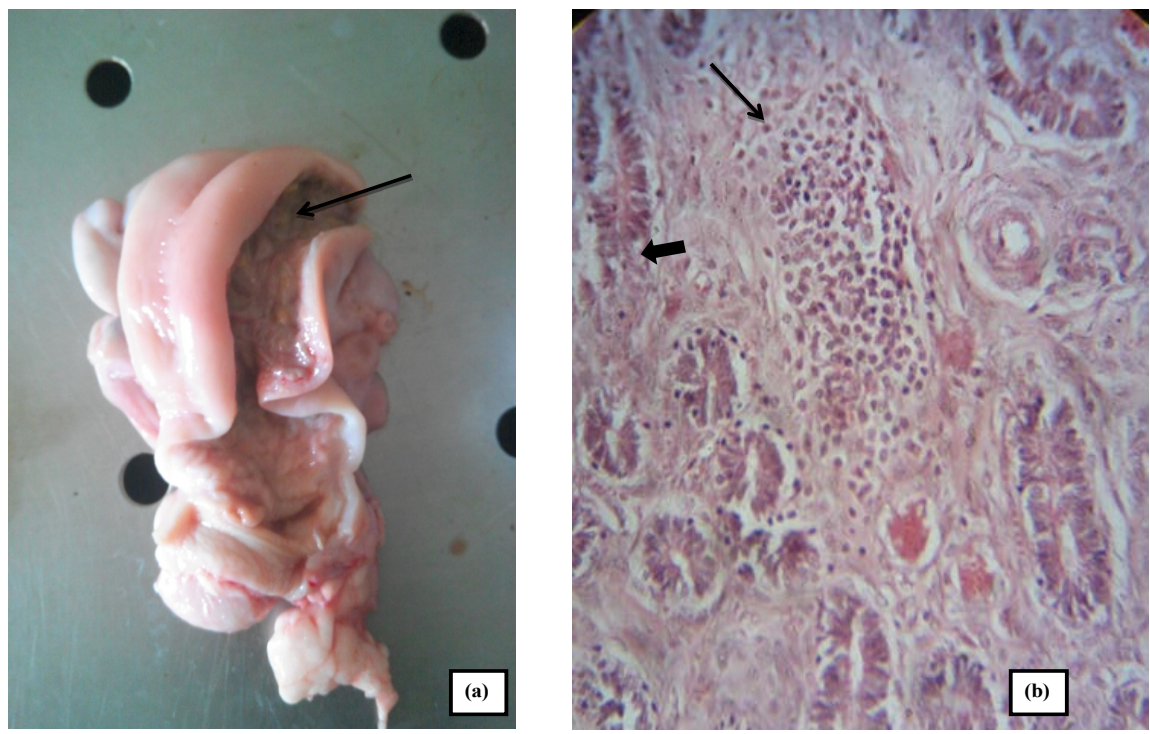

Figure 1. Chronic endometritis. Note the fibrino-necrotizing area and yellowish fibrinous exudate covering caruncles and intercaruncular space (arrow) (a). Periglandular fibrosis (thick arrow), diffused lymphocytic infiltrations in endometrial stroma (thinarrow), increase in number and disruption of endometrial glands (b). $(\mathrm{H} \& \mathrm{E} \times 10)$. 


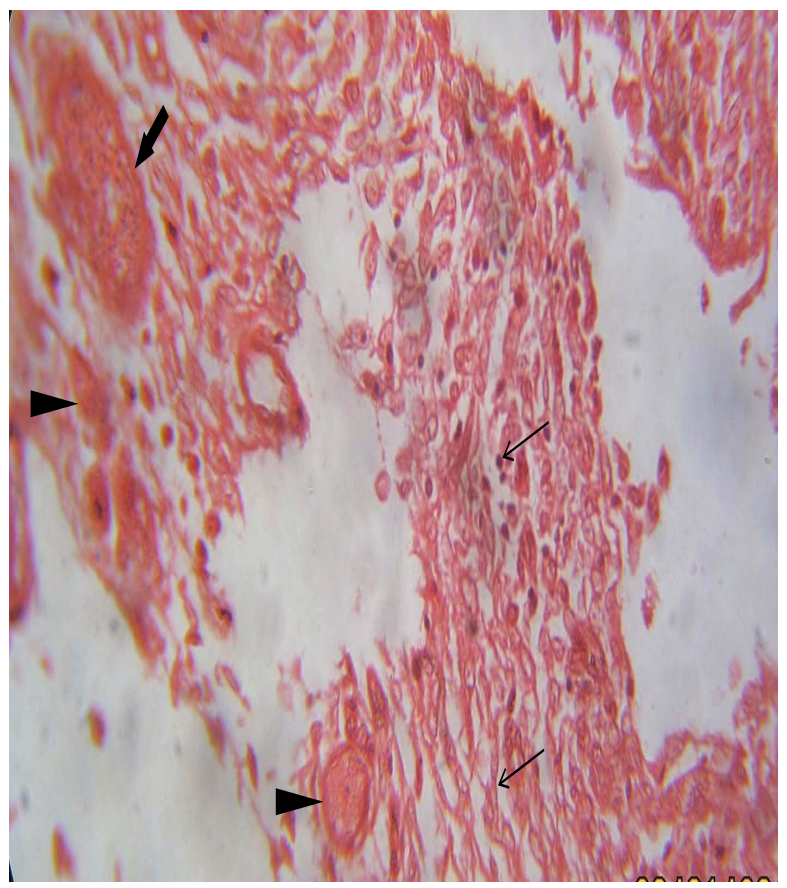

Figure 2. Granulomatous endometritis. Note the necrotic area with granules in the matrix (thick arrows) and granuloma with foci of calcification (arrow heads). Note the endometrial fibrosis and few mononuclear cell (thin arrows). ( $\mathrm{H} \& \mathrm{E} \times 10)$.

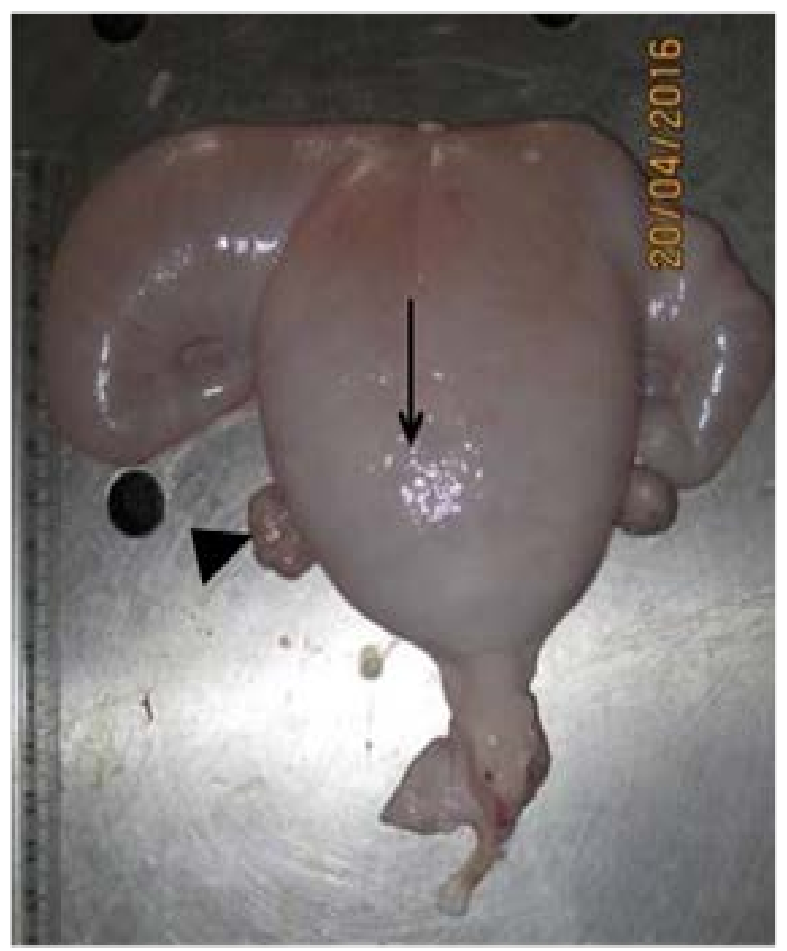

Figure 3. Hydrometra: Note the translucent uterine wall and the distension of the uterus and both horns with fluid (arrows). Note corpus luteum (arrow head). 

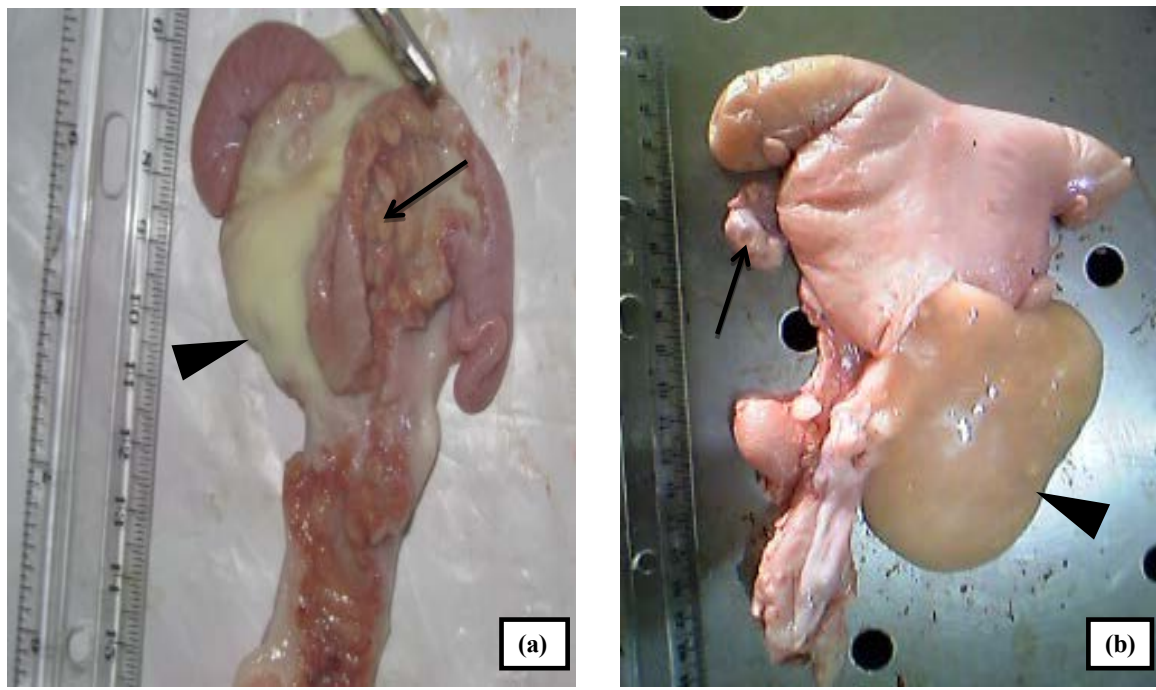

Figure 4. Pyometra. Note the necrotic uterine glands (arrow) and cream coloured pus in the uterus (arrow head) (a). Note the closed cervix and yellow to brown pus exuding from the uterus when cut opened (arrow head) and corpora lutea evident on left ovary (arrow) (b).
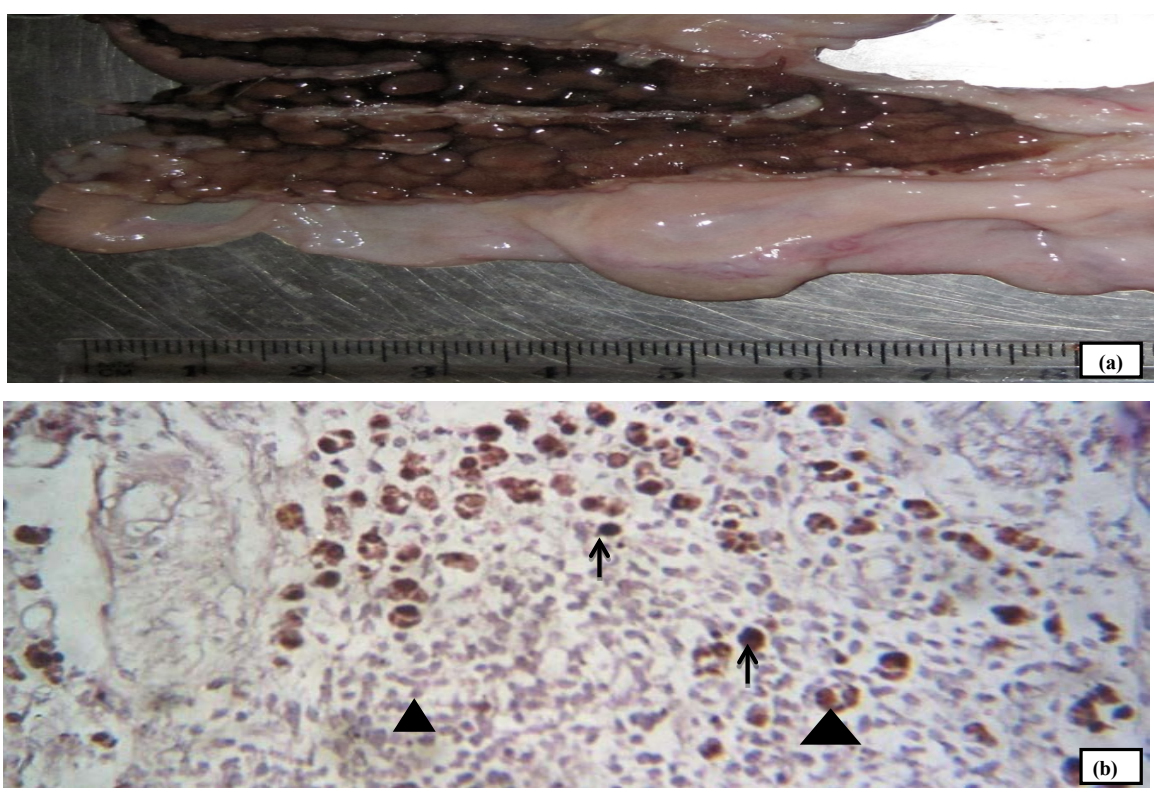

Figure 5. Uterine melanosis (grossly) with brown-black pigmented deposits on the caruncular and inter-caruncular space of the endometrium (arrow) (a). Note the multifocal brown pigmented areas in the endometrium (arrows) with macrophages and lymphocytic infiltrations (arrow heads) (b). (H \& E ×40).

ovarian lesions was $62.5 \%$ and $61.9 \%$ of RS does and WAD does, respectively. However, ovaro-bursal adhesion was the common pathological conditions of the ovary and was higher in RS does (21.2\%) as compared to WAD does (12.4\%). Bilateral bursal adhesions (Figure 9) to the ovary and the oviduct occurred in 10 (9.6\%) and $8(8.3 \%)$ cases of RS and WAD does, respectively. However, the right ovary $11(10.6 \%)$ was the most affected in the RS does. Cystic Graffian follicles 

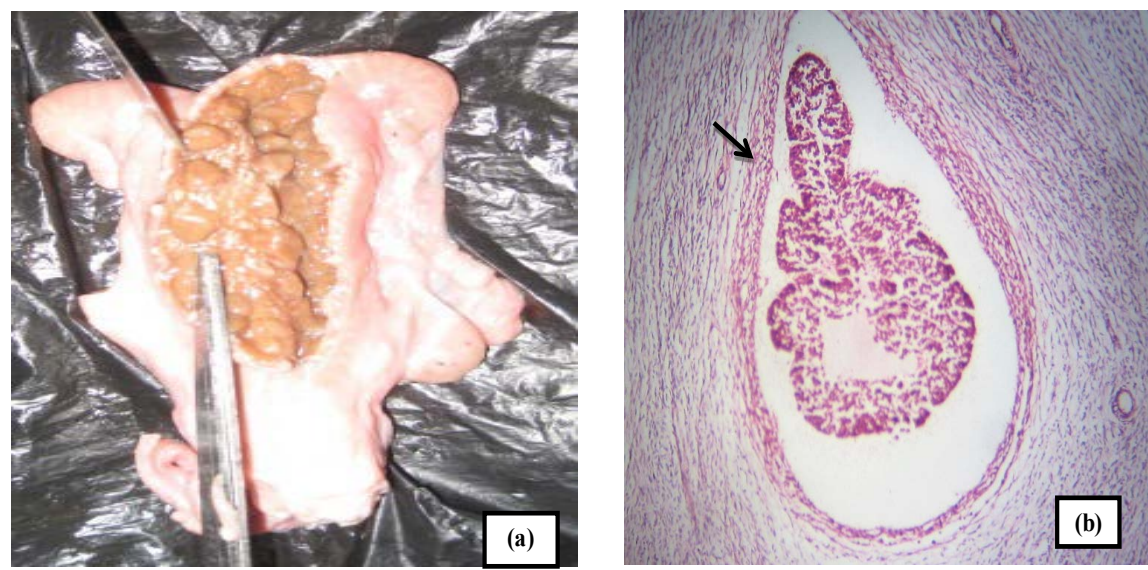

Figure 6. Endometrial (Cystic) hyperplasia. Note the multifocal white foci (grossly) (a). Cystic gland (arrow) surrounded by rims of inflammatory cells (b). ( $\mathrm{H} \& \mathrm{E} \times 10)$. Note the endometrial glands distension (c) (arrows). ( $\mathrm{H} \& \mathrm{E} \times 10)$.

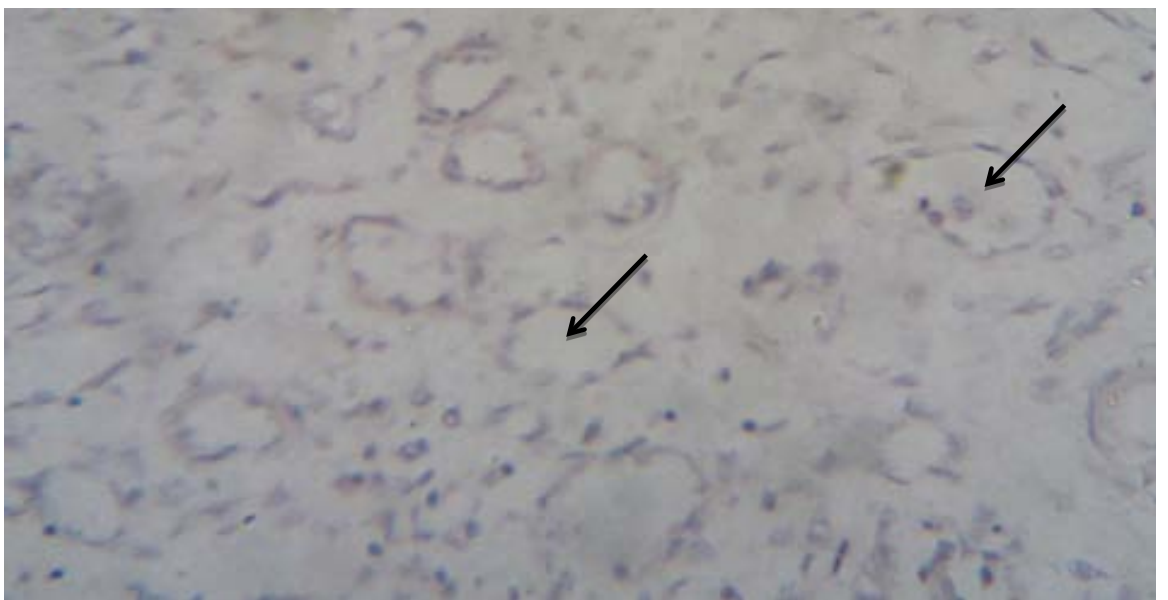

Figure 7. Post-parturient emphysematous metritis. Note the air spaces in the degenerative myometrium (arrows) and few mononuclear cells. $(\mathrm{H} \& \mathrm{E} \times 40)$.

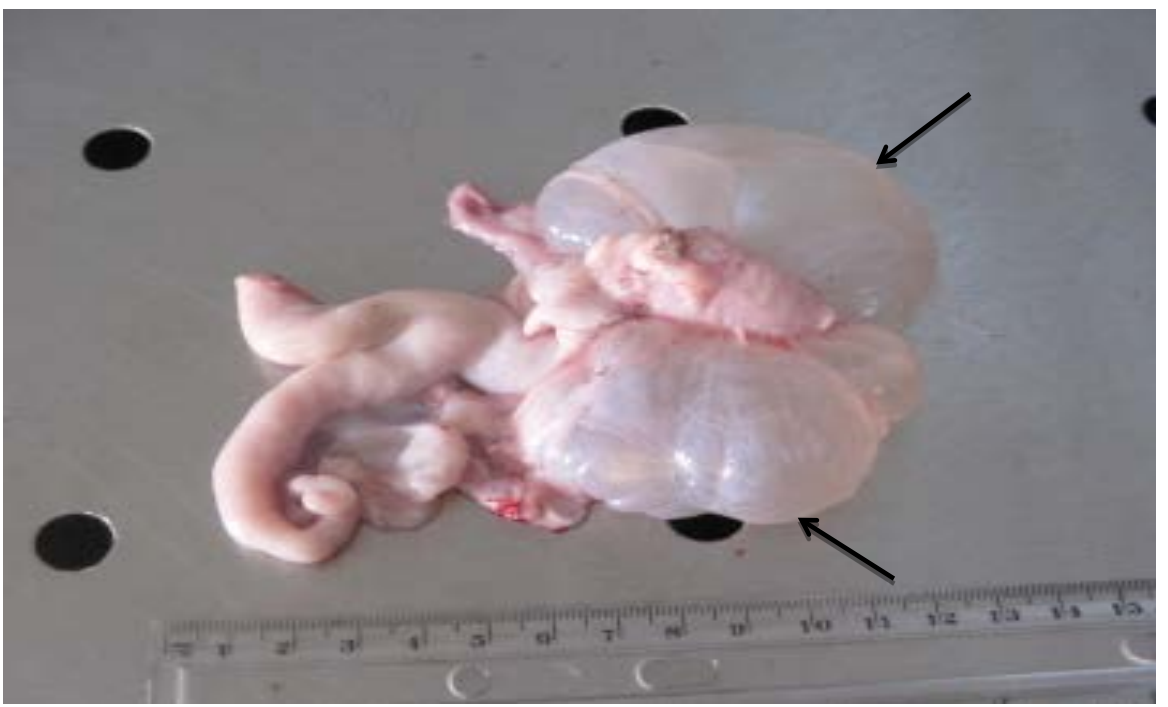

Figure 8. Cysticercus tenuicolis cyst (arrows) attached to the uterine body bilaterally. 


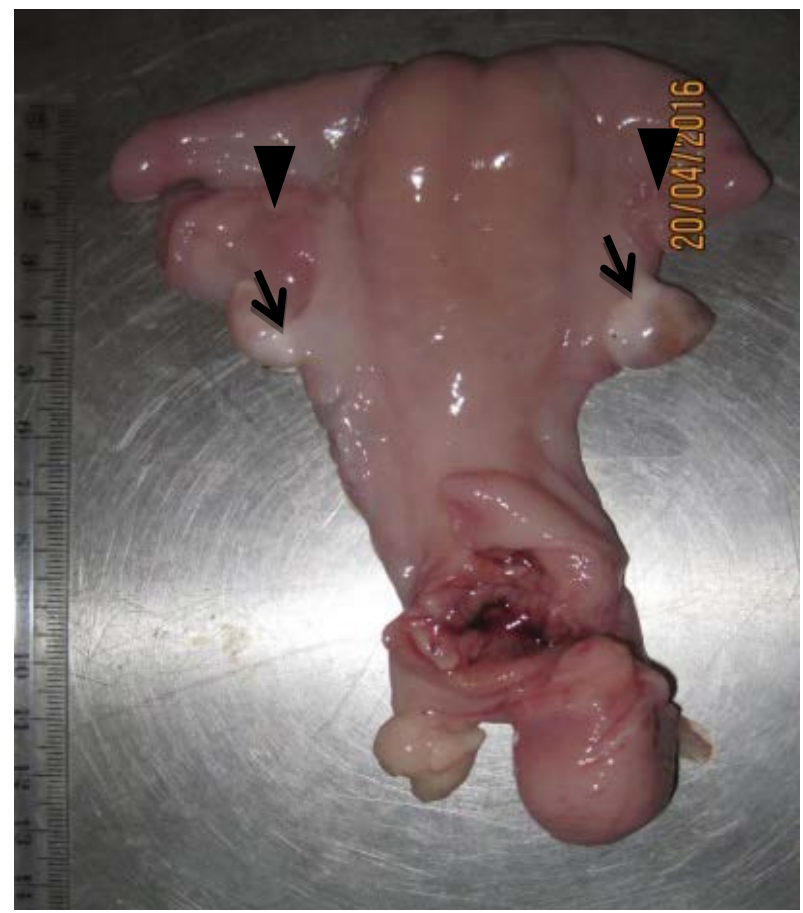

Figure 9. Bilateral ovaro-bursal (arrows) and tubo-bursal adhesions (arrow heads). Note the bursal attachments by means of a white to creamy fibrinous material (arrows).

Table 5. Prevalence of ovarian lesions in RS and WAD does.

\begin{tabular}{|c|c|c|c|c|c|c|}
\hline \multirow{3}{*}{ Lesion } & \multicolumn{4}{|c|}{ Breed } & \multirow{2}{*}{\multicolumn{2}{|c|}{$\begin{array}{c}\text { Prevalence } \\
(\%)\end{array}$}} \\
\hline & \multirow{3}{*}{ Number affected } & $S$ & \multicolumn{2}{|c|}{ WAD } & & \\
\hline & & $\begin{array}{c}\% \text { affected } \\
\text { out of } 104 \text { genital }\end{array}$ & $\begin{array}{l}\text { Number } \\
\text { affected }\end{array}$ & $\begin{array}{c}\% \text { affected } \\
\text { out of } 97 \text { genital }\end{array}$ & $\begin{array}{c}\text { RS } \\
(\mathrm{n}=211)\end{array}$ & $\begin{array}{c}\text { WAD } \\
(n=224)\end{array}$ \\
\hline & & lesions & & lesions & & \\
\hline Ovario-bursal adhesions & 22 & 21.2 & 12 & 12.4 & 10.4 & 5.4 \\
\hline tubo-bursal adhesions & 4 & 3.9 & 5 & 5.2 & 1.9 & 2.2 \\
\hline Follicular cyst & 7 & 6.7 & 5 & 5.2 & 3.3 & 2.2 \\
\hline Luteal cyst & 2 & 1.9 & 0 & 0.0 & 1.0 & 0.0 \\
\hline Cystic corpora lutea & 6 & 5.8 & 4 & 4.1 & 2.8 & 1.8 \\
\hline Oophoritis & 1 & 1.0 & 4 & 4.1 & 0.5 & 1.8 \\
\hline Ovarian hypoplasia & 5 & 4.8 & 10 & 10.3 & 2.4 & 4.5 \\
\hline Ovarian inactivity & 9 & 8.7 & 11 & 11.3 & 4.3 & 4.9 \\
\hline Paraovarian cyst & 7 & 6.7 & 7 & 7.2 & 3.3 & 3.1 \\
\hline Cysticercus tenuicolis cyst & 2 & 1.9 & 2 & 2.1 & 1.0 & 0.9 \\
\hline
\end{tabular}

No significant difference $(P>0.05)$ in left and right ovarian lesions between RS and WAD does, respectively. No significant difference $(P>0.05)$ between left and right ovarian lesions across RS and WAD does.

(Figure 10) included follicular and luteal cysts were found. Follicular cyst occurred in 7(6.7\%) and 5 (5.2\%) of RS and WAD does, respectively, while luteal cyst $2(1.9 \%)$ was found in RS only. They occurred as single cysts of about 12 $\mathrm{mm}$ to $15 \mathrm{~mm}$ in diameter and were unilateral. Seven follicular cyst (5-left sided 


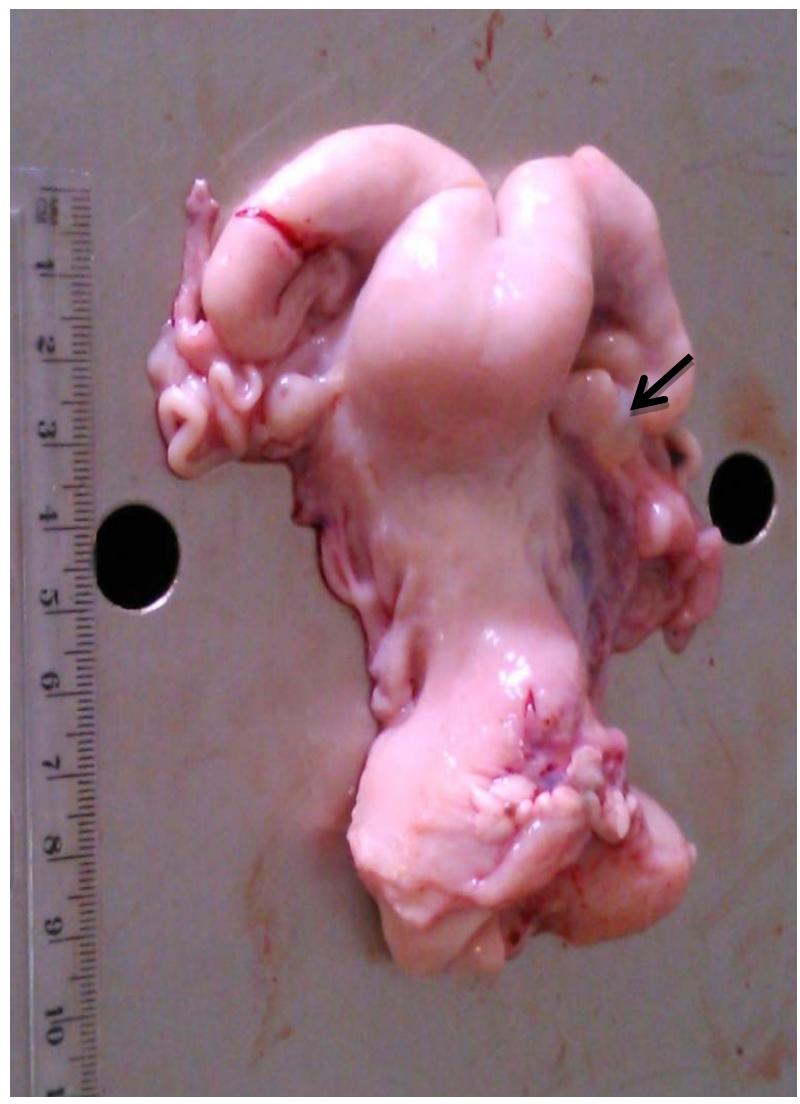

Figure 10. Cystic Graffian follicle. A unilateral cyst $(1.2 \mathrm{~cm}$ in diameter) with a transparent wall containing clear fluid on the right ovary (arrow).

and 2-right sided) in RS and five unilateral (2-left sided and 3-right sided) were found. Two cases of right-sided luteal cyst occurred. Follicular cysts were either yellowish or milky white in colour with a transparent wall containing clear fluid which pits on pressure. The cystic follicular walls were thinner and made of degenerative granulosa cells and a partially luteinised thecal cell layer. In cross section, the luteal cysts walls were about thick with meaty like consistency. There was fibrous connective tissue encapsulation around the luteal body, proliferation of connective tissue in the ovarian cortex and multi-layers of lutein granulosa cells with area of vacuolization. One case of cystic follicles was found in association with tubo-bursal cyst in RS of $13-24$ months old age group. The $>36$ months old age group was the most affected.

Paraovarian cysts (Figure 11) (1.6\%) each of RS and WAD does. They were unilateral (1-left sided and 6-right sided) in RS while in WAD (3-left sided and 4-right sided). The right ovary is the most affected. Inactive ovaries $(8.7 \%$ and $11.2 \%$ ) were recorded in RS and WAD does, respectively (Table 5). Eleven cases were bilateral in both RS and WAD while nine cases were unilateral (1-left sided and 3-right sided in RS while 4-left sided and 1-right sided in WAD). The ovaries were devoid of mature follicles $(<4 \mathrm{~mm})$ in diameter and/or corpora lutea and its degenerative stages or hypoplasia in some cases. 


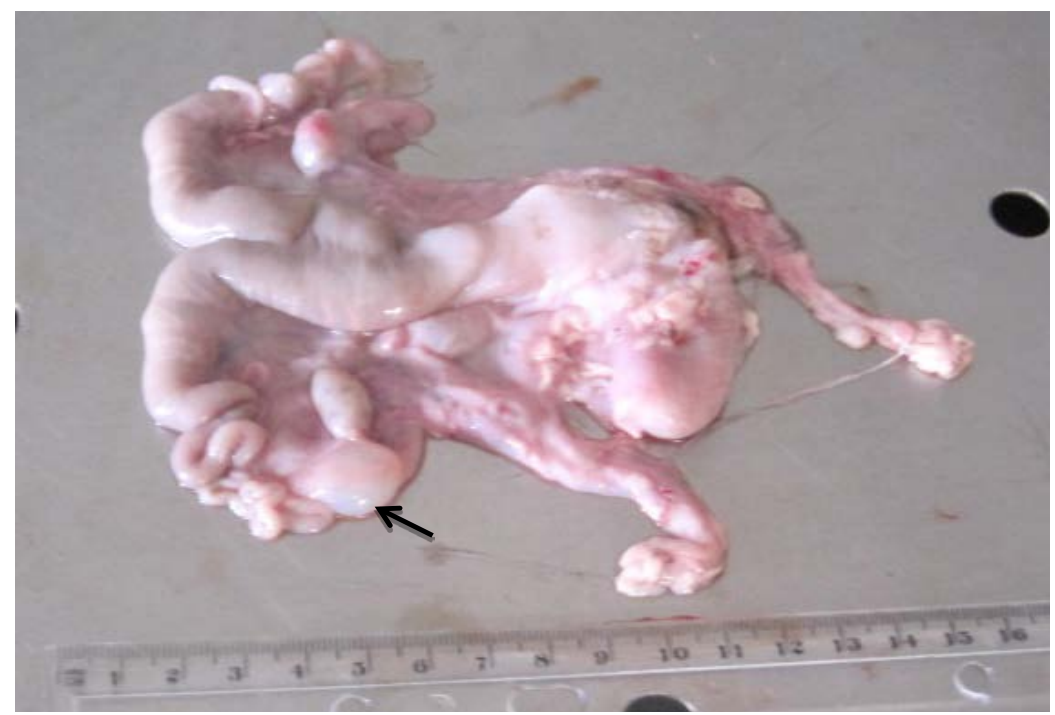

Figure 11. Paraovarian cyst attached to the right ovarian bursa (arrow).

Ovarian hypoplasia (Figure 12(a)) was found in 5 (4.8\%) and $10(10.3 \%)$ of RS and WAD does, respectively, (Table 5). The prevalence was higher in WAD (4.5\%) than in RS (2.5\%). One bilateral and two unilateral case in RS while in WAD four are bilateral and six unilateral (4-right sided and 2-left sided) were observed. The ovaries appeared "V", "C" and bean-shaped with no visible follicles or corpus luteum on the ovaries (Figure 12(a), Figure 12(b)). Histology revealed fibrosis around the oocytes with distortion of zona pellucida. Granulosa theca cells and the tunica albuginea were thickened and the ovarian cortex was reduced in thickness and contained some atretic follicles (Figure 12(d)).

Other ovarian lesions found in RS and WAD include: Cysticercus tenuicolis cyst (Figure 13) (0.5\%), Cystic corpora lutea (5.8\% and 4.1\%), each and Oophoritis $(1.0 \%$ and $4.1 \%)$. There was no significant difference $(\mathrm{P}>0.05)$ in lesions found on left and right ovary between RS and WAD does, respectively.

The prevalence rate of salpingitis in RS (1.9\%) does was lower as compared to WAD (3.1\%) does (Table 6). Hydrosalpinx (Figure 14) prevalence rate of 1.0\% in RS does and $0.5 \%$ in WAD does were recorded (Table 6). Bilateral salpingitis was more common than unilateral (left or right) and occurred more in the RS (3.0\%) as compared to that in WAD (2.1\%) while unilateral hydrosalpinx was more common and occurred more in RS does (1.0\%) each of left and right and only on the left salpinx in WAD doe (1.0\%) (Table 6). Tubo-bursal cysts (Figure 15) occurred in 7 (6.7\%) of RS and were higher than $2(2.1 \%)$ of WAD does (Table 6). There was no significant difference $(P>0.05)$ in lesions found on the left and right salpinx between RS and WAD does, respectively, and between left and right salpingeal lesions in RS and WAD does.

Cervicitis was higher in RS does (2.8\%) as compared to WAD does $(1.8 \%)$ (Table 7). They were characterized by cervical mucosa hyperaemia and lined by thin serosanguinous exudates. Necrosis and sloughing of the mucosal epithelium in few cases and diffuse mucosal infiltration by lymphocytes were observed. 

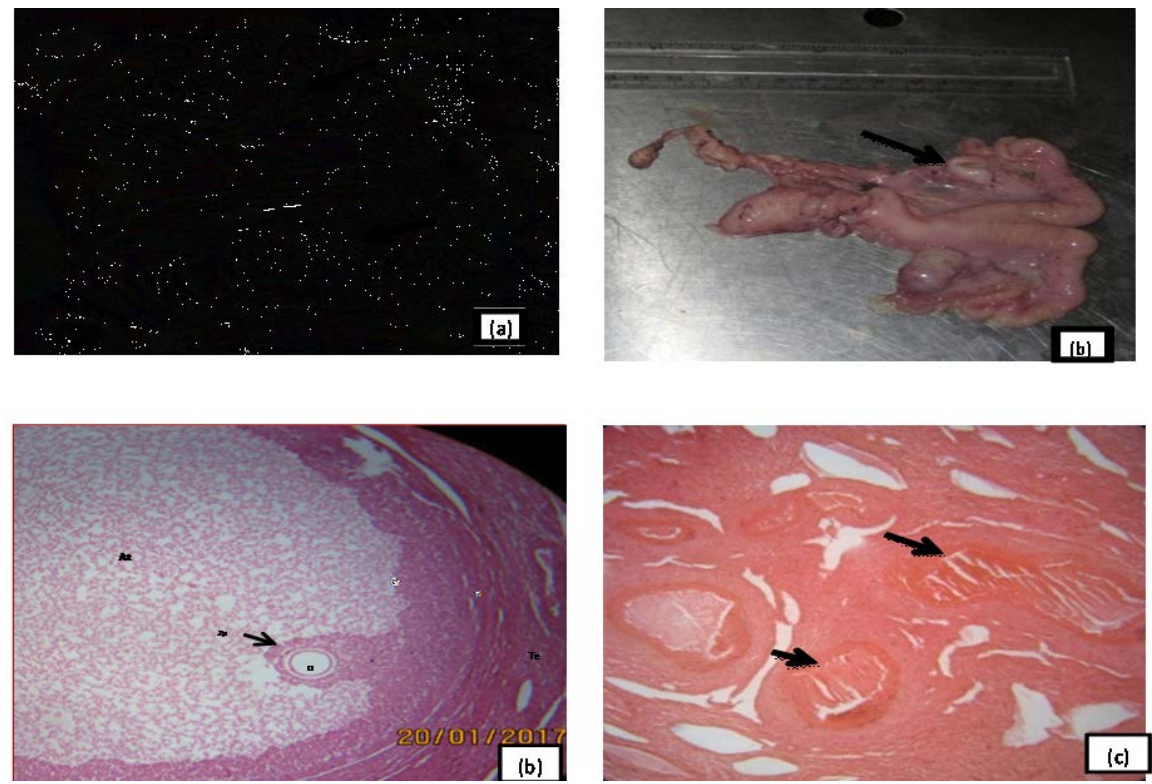

Figure 12. Hypoplastic ovary (arrow) (a) \& (b). Normal ovarian follicle (C) (H \& E ×10). Note the area of fibrosis around the follicles and distortion of follicle shape (arrows) due to hypoplasia $(\mathrm{d})(\mathrm{H} \& \mathrm{E} \times 10) . \mathrm{Gr}=$ Granulosa cells, $\mathrm{Zp}=$ Zona pellucida, $\mathrm{O}=$ Oocyte, $\mathrm{Ar}$ $=$ Antrum, $\mathrm{Ti}=$ Thecainterna, $\mathrm{Te}=$ Thecaexterna.

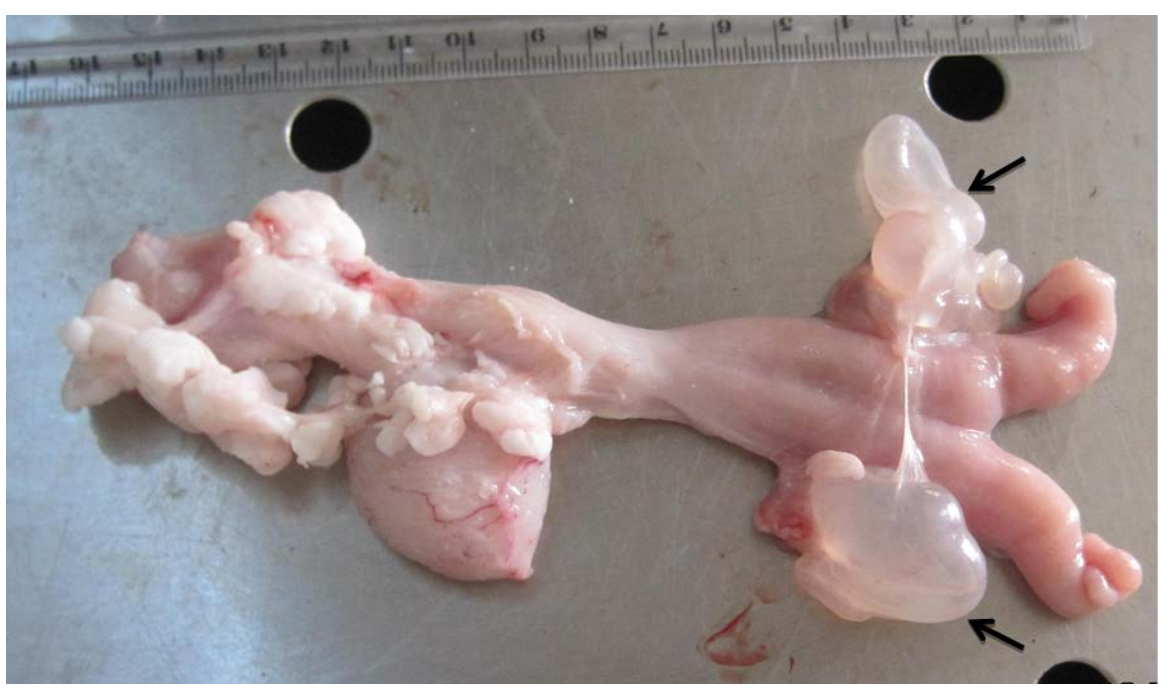

Figure 13. Cysticercus tenuicollis cyst (arrows) attached to both ovaries.

Haemorrhagic necrotising cervicitis (Table 7). The external cervical opening was dilated and hemorrhagic (Figure 16(a)). Necrosis of the cervical wall and diffuse infiltration by lymphocytes and few macrophages were observed microscopically (Figure 16(b)). Other cervical lesions include: haemorrhage (3.2\% and $0.5 \%$ in RS and WAD, respectively), and calcification of caudal cervical rugae $(0.5 \%)$ (Figure 17). There was no significant difference $(P>0.05)$ in cervical lesions between RS and WAD does.

The prevalence of vaginal hyperaemia was $0.5 \%$ each of RS and WAD does and vaginal haemorrhage occurred in $1.0 \%$ of RS and none occurred in WAD 
Table 6. Prevalence of salpingeal lesions in RS and WAD does.

\begin{tabular}{|c|c|c|c|c|c|c|}
\hline \multirow{4}{*}{ Lesion } & \multicolumn{4}{|c|}{ Breed } & \multirow{2}{*}{\multicolumn{2}{|c|}{$\begin{array}{c}\text { Prevalence } \\
(\%)\end{array}$}} \\
\hline & \multicolumn{2}{|c|}{ RS } & \multicolumn{2}{|c|}{ WAD } & & \\
\hline & $\begin{array}{l}\text { Number } \\
\text { affected }\end{array}$ & $\begin{array}{c}\% \text { affected } \\
\text { out of } 104 \text { genital }\end{array}$ & $\begin{array}{l}\text { Number } \\
\text { affected }\end{array}$ & $\begin{array}{c}\% \text { affected } \\
\text { out of } 97 \text { genital }\end{array}$ & $\begin{array}{c}\mathrm{RS} \\
(\mathrm{n}=211)\end{array}$ & $\begin{array}{c}\text { WAD } \\
(n=224)\end{array}$ \\
\hline & & lesions & & lesions & & \\
\hline Salpingitis (overall) & 4 & 3.9 & 7 & 7.2 & 1.9 & 3.1 \\
\hline a) Left oviduct & 0 & 0.0 & 4 & 4.1 & 0.0 & 1.8 \\
\hline b) Right oviduct & 1 & 1.0 & 1 & 1.0 & 1.4 & 0.5 \\
\hline c) Bilateral & 3 & 3.0 & 2 & 2.1 & 1.4 & 0.9 \\
\hline Hydrosalpinx (overall) & 2 & 1.9 & 1 & 1.0 & 1.0 & 0.5 \\
\hline a) Left oviduct & 1 & 1.0 & 1 & 1.0 & 0.5 & 0.5 \\
\hline b) Right oviduct & 1 & 1.0 & 0 & 0.0 & 0.5 & 0.0 \\
\hline Tubo-bursal cyst & 7 & 6.7 & 2 & 2.1 & 3.3 & 0.9 \\
\hline
\end{tabular}

No significant difference $(P>0.05)$ in left and right salpingeal lesions between RS and WAD does, respectively.

Table 7. Prevalence of cervical lesions in RS and WAD does.

\begin{tabular}{|c|c|c|c|c|c|c|}
\hline \multirow{4}{*}{ Lesion } & \multicolumn{4}{|c|}{ Breed } & \multirow{2}{*}{\multicolumn{2}{|c|}{$\begin{array}{c}\text { Prevalence } \\
(\%)\end{array}$}} \\
\hline & \multicolumn{2}{|r|}{ RS } & \multicolumn{2}{|c|}{ WAD } & & \\
\hline & $\begin{array}{l}\text { Number } \\
\text { affected }\end{array}$ & $\begin{array}{c}\% \text { affected } \\
\text { out of } 104 \text { genital }\end{array}$ & $\begin{array}{l}\text { Number } \\
\text { affected }\end{array}$ & $\begin{array}{c}\% \text { affected } \\
\text { out of } 97 \text { genital }\end{array}$ & $\begin{array}{c}\mathrm{RS} \\
(\mathrm{n}=211)\end{array}$ & $\begin{array}{c}\text { WAD } \\
(n=224)\end{array}$ \\
\hline & & lesions & & lesions & & \\
\hline Cervicitis (overall) & 6 & 5.7 & 4 & 4.1 & 2.8 & 1.8 \\
\hline 1) Chronic cervicitis & 0 & 0 & 1 & 1.0 & 0.0 & 0.5 \\
\hline 2) Acute (non-suppurative) Cervicitis & 3 & 2.9 & 3 & 1.0 & 1.4 & 1.3 \\
\hline 3) Hemorrhagic necrotizing cervicitis & 3 & 2.9 & 0 & 0.0 & 1.4 & 0.0 \\
\hline Cervical haemorrhages & 7 & 6.7 & 1 & 1.0 & 3.2 & 0.5 \\
\hline Calcification of caudal cervical rugae & 1 & 1.0 & 0 & 0.0 & 3.2 & 0.0 \\
\hline
\end{tabular}

Nosignificant difference $(\mathrm{P}>0.05)$ of cervical lesions between RS and WAD does.

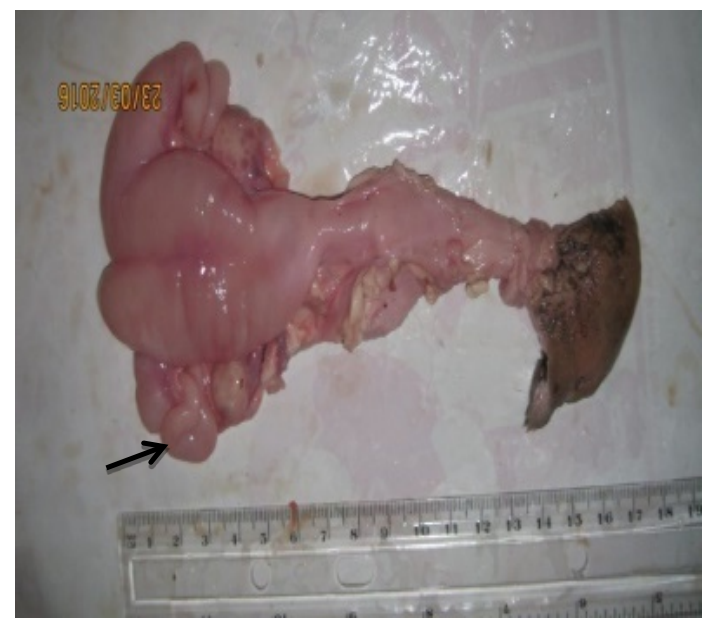

Figure 14. Hydrosalpinx (arrow) in association with hydrometra. 


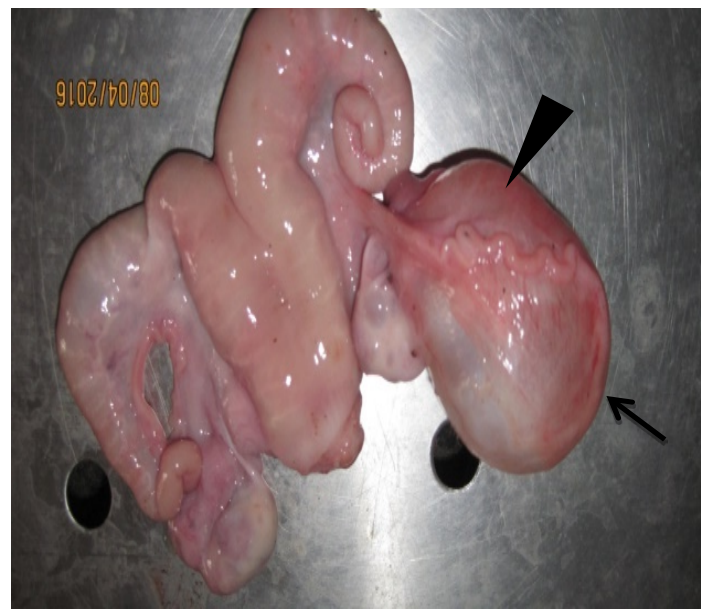

Figure 15. Tubo-bursal cyst: note the fluid filled cyst (arrow head) with distention of the oviduct and left ovarian bursa (arrow).
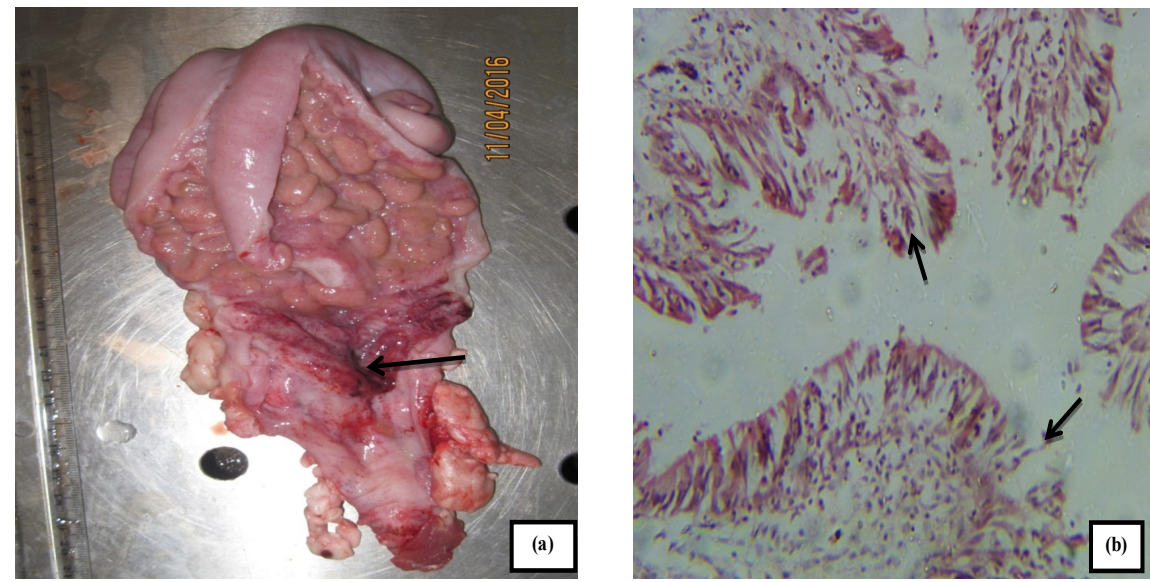

Figure 16. Haemorrhagic necrotizing cervicitis (arrow) (a). Note the cervical haemorrhage (arrow) (a). Disquamation of lamina epithelium (arrows) and cellular infiltration due to necrotizing cervicitis (b). ( $\mathrm{H} \& \mathrm{E} \times 10)$.

(Table 8). There was no significant difference $(\mathrm{P}>0.05)$ in vaginal lesions between RS and WAD does.

\section{Discussion}

Results of the present study show that the occurrence of female genital lesions in the two breeds of $49.3 \%$ and $43.3 \%$, respectively, were high compared to the findings of [11] [13] [22], in Indian goats [15], in Nigeria and [19] in Uganda, who reported prevalence of $1.9 \%$ to $23.32 \%$ of female genital disorders in goats, respectively. Although no statistical difference $(\mathrm{P}>0.05)$ in the occurrence of genital pathologies between RS and WAD in the present study, the high prevalence may have been due to breed difference and environmental effect.

The prevalence of genital lesions was highest in the $13-24$ months age group in RS and WAD breeds, respectively, in the present study. This could mean that 

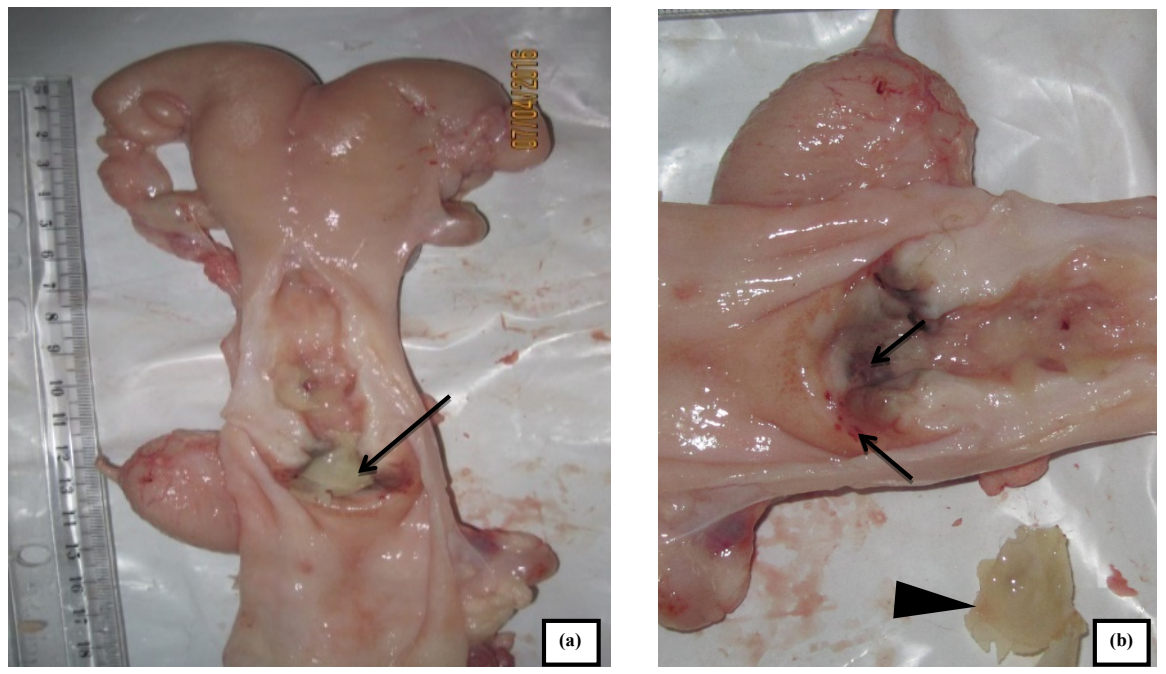

Figure 17. Calcification of caudal cervical rugae. Note the calcified material in the cervix (arrow) (a). Note the hemorrhages (arrow) and area of necrosis in the caudal cervical rugae (arrow). Note the calcified material removed from the cervix (arrow head) (b).

Table 8. Prevalence of vaginal lesions in RS and WAD does.

\begin{tabular}{|c|c|c|c|c|c|c|}
\hline \multirow{4}{*}{ Lesion } & \multicolumn{4}{|c|}{ Breed } & \multirow{2}{*}{\multicolumn{2}{|c|}{$\begin{array}{c}\text { Prevalence } \\
(\%)\end{array}$}} \\
\hline & \multicolumn{2}{|r|}{ RS } & \multicolumn{2}{|c|}{ WAD } & & \\
\hline & $\begin{array}{l}\text { Number } \\
\text { affected }\end{array}$ & $\begin{array}{c}\% \text { affected } \\
\text { out of } 104 \text { genital }\end{array}$ & $\begin{array}{l}\text { Number } \\
\text { affected }\end{array}$ & $\begin{array}{c}\% \text { affected } \\
\text { out of } 97 \text { genital }\end{array}$ & $\begin{array}{c}\mathrm{RS} \\
(\mathrm{n}=211)\end{array}$ & $\begin{array}{c}\text { WAD } \\
(n=224)\end{array}$ \\
\hline & & lesions & & lesions & & \\
\hline Vaginal hyperaemia & 1 & 1.0 & 1 & 1.0 & 0.5 & 0.5 \\
\hline Haemorrhage & 2 & 1.9 & 0 & 0.0 & 1.0 & 0.0 \\
\hline
\end{tabular}

No significant difference $(\mathrm{P}>0.05)$ in vaginal lesions between RS and WAD does.

age is an important intrinsic factor that contributes to the distribution of reproductive abnormalities. This agrees with findings of [15] and [16] who reported that susceptibility to reproductive disease increases with age. Thus, the high occurrence of genital tract pathology in this age group may have been due to their active reproductive age. This is in line with the report of [27] and [28]. Hence, this age group is more prone to different pathological changes of the genital tracts. However, there was no statistical correlation in age and lesions between RS and WAD in this study.

Pathological conditions of the uterus of RS (38.4\%) and WAD (25.6\%) were lower than earlier reports of $53.24 \%, 41.34 \%$ and $70 \%$ by [11] [14] and [29] in Iranian and India does, respectively, but higher than that reported [15] of 14.6\% goats.

Previous studies show that endometritis occurred as the most common pathological condition in caprine uterus collected from local abattoirs [30] [31]. The prevalence in RS (11.9\%) and WAD (7.2\%), however, are higher than the report of 3.9\% [15], 4\% [14] [31] [32] [33], 4.46\% [30], 5.8\% [34] and 5.6\% [11] in goats but lower than the reports of $24.76 \%$ [29] and $13.7 \%$ [35] in ewes. The 
cause could be due to unhygienic management practices or ascending infections, though not life-threatening, it may cause embryonic loss by disruption of uterine tissue or by direct cytolysis of embryo [36] [37] [38] [39].

Chronic endometritis in this study was higher than reports of 3.8\% [11], 3.9\% [15], and $0.9 \%$ [40] in goats. Chronic endometritis is usually associated with varying degrees of infertility depending on the extent of endometrial damage. Acute endometritis with prevalence of $3.8 \%$ and $2.7 \%$ of RS and WAD does, respectively, in this studies was higher than similar reports of $1.36 \%$ [11] and $2.0 \%$ [15] in goats and $0.5 \%$ [41] and $0.45 \%$ [42] in ewes.

Uterine haemorrhage was reported in 30 out of 1200 (2.5\%) goats [15], which was much lower than current findings. Although the high figures in this study may have been due to sample size. Average occurrence of hydrometra in Brazilian and Dutch dairy goats was reported to be $10.4 \%$ and $9 \%$ [43] [44] [45], respectively. These finding were much higher than $1.9 \%$ (RS) and 1.3\% (WAD) in the present study. Ithas been observed that difference in breeds of goats does nothave any influence on hydrometra incidence [46]. Hydrometra have been shown to cause infertility by interfering with embryo attachment to the endometrium as a result of glandular changes thereby impeding the success of pregnancy [47] [48].

Occurrence of pyometra in this study was consistent with other reports in ewes, does and cattle [17] [29] [32] [42] [49] [50] [51]. Other studies reported lower findings of $0.4 \%, 0.1 \%$ [9] [41] [52], respectively, in ewes and does. However, the prevalence of $81.8 \%$ [53] in goats, $8.0 \%, 100 \%$, and $7.1 \%$ [53] [54] [55], respectively, in ewes, were higher than figures obtained in this study. Pyometra may ensue when sufficient damage to endometrium occur, thereby preventing $\mathrm{PGF}_{2 \alpha}$ production to lyse corpus luteum with persistent production of progesterone causing closure of the cervix and making the uterus more susceptible to infection and prohibits pregnancy success [55] [56] [57]. Poor reproductive management (postpartum care, unhygienic environment) and genital infections predisposed by postpartum complications (dystocia, abortion, retained fetal membranes, coitus and a prolonged luteal phase) have been reported to cause pyometra [9] [50] [58].

Salpingitis (1.9\%) and (3.1\%) in RS and WAD, respectively, in this study were higher than previous reports in goat of $0.45 \%, 0.8 \%, 0.3 \%$ and $0.57 \%$ [15] [34] [49] [59], respectively, but lower than the report of 3.7\% [9]. It has been commonly associated with secondary or nonspecific infections ascending from the uterus [60]. Bilateral hydosalpinx causes sterility but unilateral hydroslpinx and mild salpingitis have been reported to cause varying degrees of infertility in goats since the sloughed or degenerated epithelium is unable to support ovum survival [9] [36] [60]. Hydrosalpinx, like hydrometra, can lead to infertility and subfertility, since intraluminal fluid interferes with embryo attachment [48].

Most of the ovaro-bursal adhesions in this study occurred unilaterally (right-sided)in association with inflammatory conditions of uterus, ovary and salpinx and the figures obtained in RS (10.4\%) and WAD (5.4\%) were higher 
compared to $3.7 \%, 0.45 \%, 1.9 \%$ and $2.99 \%$ [9] [11] [15] [61] in goats, respectively. The result of this study is consistent with 6.36\% [52] reported in ewes. [15] reported that chronic pelvic inflammatory reaction sequential to previous abortions or post-partum complications seems to be the cause of ovaro-bursal adhesions. The incidence was more prevalent in the RS compared to WAD does. Ovaro-bursal and tubo-bursal adhesions can cause infertility by interfering with ovulation and/or the passage of ova into the oviduct [9] [61] [62] [63].

The prevalence of cystic Graffian follicle in RS (4.3\%) and WAD (2.2\%) in this study were lower than reports of $1.2 \%, 0.9 \%$ and $0.41 \%$ [9] [11] [61] in does, respectively, $1.14 \%$ and $0.6 \%$ [41] [64] in ewes, respectively and $1.88 \%$ [59] in cows but consistent with finding of $4.3 \%$ [65] in ewes. One case of follicular cyst was found in association with tubo-bursal cyst which agrees with similar finding in goat [9]. Cystic ovarian disease is idiopathic; insufficient releases of luteinising hormone, heredity, phosphorous deficiency and oestrogenic pastures have been implicated as the cause [66] [67] [68].

[55] and [61] reported $1.0 \%$ and $0.55 \%$ of ovarian hypoplasia in ewes and does, respectively, which were lower than the $2.4 \%$ in RS does and $4.5 \%$ in WAD in this study. Ovarian hypoplasia in this study was characterized by the incomplete development or ovarian dysgenesis and ovary lacking in primordial follicles. The cause could not be established in this study but like many other ovarian abnormalities, it can cause anestrous.

The prevalence Cysticercus tenuicolis cysts of $1.5 \%$ in RS and $1.4 \%$ in WAD in this study were higher than previous reports of $0.1 \%$ [9]. They were found on the uterine body and attached to the ovarian pole and occurred bilateraly and unilateral in this study. This agrees with previous report by [23]. Cysticercus tenuicolis cysts and paraovarian cysts can impair fertility if exerting pressure on the oviduct [23] [69].

Cervicitis usually occurs with an overshadowing endometritis or vaginitis [59] [68], trauma (during kidding), cervical infection or unhygienic management practices in kidding pens are possible causes [3] [9]. The prevalence in this study of $2.8 \%$ (RS) and $1.8 \%$ (WAD) were higher than other documented findings of $1.4 \%$ and $0.7 \%$ [9] [39] [42], respectively, in Iraqi ewes. However, [11] reported a higher prevalence of $6.4 \%$ than the figures obtained in this study.

The abnormalities of the vagina in this study could be due to vaginal trauma e.g. during kidding, natural breeding [3], extension of utero-cervical hemorrhages [11] orinfections [70].

\section{Conclusion}

The prevalence of genital tract pathology is higher in the RS (49.3\%) as compared to WAD (43.3\%) breeds but is not statistically significant ( $\mathrm{P}>0.05)$. The two breeds suffer from genital pathologies which were predominated by the uterus, followed by those in the ovary, cervix, salpinx and vagina. Endometritis is the most common pathological lesion found followed by ovaro-bursal adhe- 
sions. Genital tract pathologies occur more in the 13 - 24 months old group which is the most active reproductive age. The genital pathologies found may cause varying degrees and potential infertility or sterility in does. The findings of this study will give a window to investigation of genital disorders on the farm and seasonal variation incidences to ascertain their possible impact on the reproductive performance of does.

\section{Acknowledgements}

The assistance and cooperation rendered by the abattoir workers during sample collection for this study is gratefully acknowledged. The authors are thankful to the Directors, Veterinary Teaching Hospital, Federal University of Agriculture, Makurdi (FUAM) and National Veterinary Research Institute (NVRI), Vom, for providing necessary facilities for this study.

\section{Conflicts of interest}

The authors declare no conflicts of interest.

\section{References}

[1] Food and Agriculture Organization (2006) FAOSTAT Database. FAO, Rome.

[2] Larmode, A.G. (1997) Animal Health and Nutrition as a Major Constraint to Improving Livestock Productivity. Paper Presented at National Workshop on Improving Agricultural Productivity of Peasant Farmers in Nigeria, $10 \mathrm{p}$.

[3] Lawal-Adebowale, O.A. (2012) Dynamics of Ruminant Livestock Management in the Context of the Nigerian Agricultural System. In: Javed, K., Ed., Livestock Production, IntechOpen, London, 61 p. https://doi.org/10.5772/52923

[4] News Agency of Nigeria (2016).

[5] Baba, S.S., Bobbo, A.G., Akoma, M.B. and Osiyemi, T.I. (1994) Slaughter House Survey for Antibodies against Selected Ruminant Sera in Maiduguri, Borno State, Nigeria. Journal of Veterinary Medicine and Animal Health, 95, 55-62.

[6] Abdullahi, A.K. (1985) An Economic Analysis of a Settlement Model for Fulani Pastoralists in Sokoto State of Nigeria. PhD Thesis, School of Agriculture, University of Nottingham, Leicestershire, $197 \mathrm{p}$.

[7] Cupps, P.T. (1991) Reproduction in Domestic Animals. 4th Edition, Academic Press Inc., Cambridge, 491-508.

[8] Ogwal-Okwot (2000) The Role of Livestock in the Eradication of Protein under Nutrition in Uganda. Uganda Veterinary Journal, 6, 169.

[9] Francis, M. (2009) Caprine Ovarian and Uterine Lesions: An Abattoir Survey. M.Sc. Thesis, Makerere University, Kampala, 6-42.

[10] Fatima, B. (2011) Cystic Endometrial Hyperplasia in Algerian Goats and Ewes. Veterinary Scan, 6, Article 84.

[11] Beena, V., Pawaiya, N., Shivasharanappa, K., Gururaj, V.K., Gupta, N.K., Gangwar, D.D., Singh, M., Karikalan, A.K., Sharma, H.K.A., Kumar and Singh, R. (2015) Occurrence of Pathological Conditions in the Female Genitalia of Goats. Indian Journal of Veterianry Pathology, 39, 197-201.

https://doi.org/10.5958/0973-970X.2015.00049.8 
[12] Wekhe, S.N. and Yahaya, M.A. (1999) Prevalence of Reproductive Abnormalities among Slaughtered House Animals in Port Harcourt City. Tropical Journal of Animal Science, 1, 175-180. https://doi.org/10.4314/tjas.v1i2.49611

[13] Virmani, N. (1993) Studies on Pathology of Female Genital Tract of Sheep and Goats. MVSc. Thesis, Indian Veterinary Research Institute, Izatnagar, 56 p.

[14] Archana, S., Vijay, M., Anita, B. and Indu, V. (2013) Pathological Study on Occurrence of Various Reproductive Diseases in Goats at Rajasthan. Journal of Immunology and Immunopathology, 15, 134.

[15] Ogunbodede, M.A., Oladele, G.M., Ode, O.J. and Ubah, S.A. (2014) Survey of Gross Abnormalities and Microbial Load on the Female Reproductive Tract of Maradi Goats Slaughtered at Bodija Abattoir, Nigeria. Advanced Journal of Agricultural Research, 2, 001-007.

[16] Butswat, I.S.R., Kalla, D.J.U., Mbap, S.T., Molokwu, J.U. and Chuo, R.B. (2001) Evaluation of the Reproductive Problems of the Friesians, Bunajis and Crossed Cows in Subtropical Environment. Nigerian Journal of Animal Production, 28, 123-127.

[17] Simenew, K., Bekana, M., Fikre, L., Tilahun, Z. and Wondu, M. (2011) Major Gross Reproductive Tract Abnormalities in Female Cattle Slaughtered at Sulta Slaughterhouses in Ethiopia. Global Veterinaria, 6, 506-513.

[18] Omudu, E.A. and Amuta, E.U. (2007) Parasitology and Urban Livestock Farming in Nigeria: Prevalence of Ova in Faecal and Soil Samples and Animal Ectoparasites in Makurdi. The South African Veterinary Association, 78, 271-278. https://doi.org/10.4102/jsava.v78i1.285

[19] Thrushfield, M. (1997) Veterinary Epidemiology. 2nd Edition, Butterworths Limited, London, $20 \mathrm{p}$.

[20] Williamson, G. and Payne, W.J. (1984) An Introduction to Animal Husbandry in the Tropics. 4th Edition, ELBS and Longman, Essex, 1098 p.

[21] Drennan, W.G. and Macpherson, J.W. (1966) The Reproductive Tract of Bovine Slaughter Heifers (a Biometrical Study). Canadian Journal of Comparative Medicine and Veterinary Science, 30, 224-227.

[22] Assey, R.J., Kessy, B.M., Matovelo, J.A. and Minga, U. (1998) Incidence of Gross Reproductive Abnormalities in Small East African Zebu Cattle. Tropical Animal Health and Production, 30, 361-368. https://doi.org/10.1023/A:1005144721298

[23] Smith, K.C., Parkinson, T.J. and Long, S.E. (1999) Abattoir Survey of Acquired Reproductive Abnormalities in Ewes. Veterinary Record, 144, 491-496. https://doi.org/10.1136/vr.144.18.491

[24] Avwioro, O.G. (2011) Staining Reactions of Microwave Processed Tissues Compared with Conventional Paraffin Wax Processed Tissues. European Journal of EXperimental Biology, 1, 57-62.

[25] Kiernan, J.A. (1990) Histological and Histochemical Methods: Theory and Practice. Pergamon Press, Oxford, 433 p.

[26] GraphPad Software Inc. (2016) GraphPad Prism Version 7.03.

[27] Arthur, G.H., Noakes, D.E. and Pearson, H. (1983) Veterinary Reproduction and Obstetrics (Theriogenology). 6th Edition, Bailliere Tindall, London, 444-456.

[28] Matthews, J. (2001) Diseases of the Goat. Blackwell Science, Hoboken, 1-51.

[29] Kassim, F., Abdul-Kareem, A., Al-Mayah, A.S. and Kaisar, D. (2007) Abnormalities of Reproductive Organs in Ewes: A Prospective Histopathological Study. Basrah Journal of Veterinary Research, 6, 97-107. 
[30] Ijapure, K.P., Singh, B.K. and Chauhan, R.A.S. (2002) Incidence of Pathological Affections of Genitalia in She Goats. Indian Veterinary Journal, 79, 298-299.

[31] Reddy, K.C.S., Reddy, V.S.C. and Rao, A.S. (1997) Studies on the Incidence of Reproductive Abnormalities in Local Non-Descript Female Goats. Indian Journal of Animal Reproduction, 18, 51-53.

[32] Biswas, H.C. (2013) Gross and Histopathological Study of Reproductive Tract of Indigenous Ewe. Ms Thesis, Department of Surgery and Obstetrics, Faculty of Veterinary Science, Bangladesh Agricultural University, Mymensingh, Bangladesh, 60 p.

[33] Ramachandran, K., Iyer, C.P.N. and Nair, K.P. (1984) Pathological Conditions in the Bursa, Salpinx and Uterus of Does. Kerala Journal of Veterianry Science, 15, 112-117.

[34] Roy, B. (2001) Pathology of Female Reproductive System of Goats in Mymensingh District of Bangladesh. MS Thesis, Department of Pathology, Bangladesh Agricultural University, Mymensingh, 30-42.

[35] Dhurova, I., Mrinov, M., Marinov, P. and Tashev, S. (1985) Morphological Changes in the Genitalia of Culled Sheep. Veterinarno-Medicinski Nauki, 22, 43-52.

[36] Acland, A.M. (2001) Reproductive System: Female. In: Thomson's Special Veterinary Pathology, 3rd Edition, Mosby Inc., St. Louis, 601-614.

[37] Gilbert, R.O., Yang, X., Jiang, S., Schlafer, D.H.V., Saluste, V. and Scheytt, A. (1995) Effects of Aseptic Inflammation on Development of Bovine Embryos In-Vivo and In-Vitro. Proceedings of the Annual Meeting of the Society for Theriogenology, San Antonio, 1995, $312 \mathrm{p}$.

[38] Hansen, P.J., Soto, P. and Natzke, R.P. (2004) Mastitis and Fertility in Cattle, Possible Involvement of Inflammation or Immune Activation in Embryonic Mortality. American Journal of Reproductive Immunology, 51, 294-301. https://doi.org/10.1111/j.1600-0897.2004.00160.x

[39] Sheldon, I.M. and Dobson, H. (2004) Postpartum Uterine Health in Cattle. Animal Reproductive Science, 82-83, 295-306. https://doi.org/10.1016/j.anireprosci.2004.04.006

[40] Timurkaan, F. and Ozer, H. (2002) Uterus Didelphys in a Goat. Veterinary Record, 151, 217. https://doi.org/10.1136/vr.151.7.217

[41] Benchaib, F. and Aldahash, S.Y. (2002) Gross Abnormalities Affecting Genital Tracts of Algerian Ewes, Assiut, Egypt. Veterinary Medical Journal, 47, 199-203.

[42] Timurkaan, F. and Karadas, E. (2000) Morphological Investigations on Pathological Changes of the Female Reproductive Organs in Goats: Ovarium and Oviduct. Firat Üniversitesi Sağlık Bilimleri Dergisi, 14, 197-207.

[43] Hesselink, J.W. and Elving, L. (1996) Pedigree Analysis in a Herd of Dairy Goats with Respect to the Incidence of Hydrometra. Veterinary Quarterly, 18, 24-25. https://doi.org/10.1080/01652176.1996.9694607

[44] Lopes, J.E.S., Cruz, J.F., Teixeira, D.I., Limaverde, J.B., Paula, N.R., Rondina, D. and Freitas, V.J. (2004) Pseudopregnancy in Saneen Goats (Capra hircus) Raised in North East Brazil (Abstract). Veterinary Research Communications, 28, 119. https://doi.org/10.1023/b:verc.0000012112.79820.e0

[45] Moraes, E.P.B.X. (2007) Hydrometra and Mucometra in Goats Diagnosed by Ultrasound and Treated with $\mathrm{PGF}_{2 \alpha^{\circ}}$ Medicina Veterinaria, 1, 33-39.

[46] Wittek, T., Richter, A., Erices, J. and Elze, K. (1997) Incidence, Diagnosis, Therapy and Subsequent Fertility in Goats with Hydrometra. Tierärztliche Praxis, 25, 
576-582.

[47] Ben-Rafael, Z. and Orvieto, R. (1992) Cytokine Involvement in Reproduction. Fertility and Sterility, 58, 1093-1099. https://doi.org/10.1016/S0015-0282(16)55548-4

[48] Chien, L.W., Au, H.K., Xiao, J. and Tzeng, C.R. (2002) Fluid Accumulation within the Uterine Cavity Reduces Pregnancy Rates in Women Undergoing IVF. Human Reproduction, 17, 351-356. https://doi.org/10.1093/humrep/17.2.351

[49] Ahmed, J.U. (1993) Incidence of Gynaeco-Obstetrical Disorders in Black Bengal Goats. BAU Research Progress, 7, 499-505.

[50] Kennedy, P.C. and Miller, R.B. (1993) The Female Genital System. In: Jubb, K.V.F., Kennedy, P.C. and Palmer, N., Eds., Pathology of Domestic Animals, 4th Edition, Academic Press, San Diego, 349-454. https://doi.org/10.1016/B978-0-12-391607-5.50012-1

[51] Khammas, D.J., Ibrahim, N.S., Buni, F.E. and Alwan, A.F. (2013) Macroscopic Study of Lesions Affecting Genital Tract of Iraqi Ewes. The Iraqi Journal of Veterinary Medicine, 37, 266-268.

[52] Iqbal, M., Safri, S.A. and Khan, S.S. (1992) A Research Note: Incidence of Various Reproductive Disorders in Female Teddy Goats in Different Age Groups. Pakistan Journal of Agricultural Research, 13.

[53] Neils, J.S., Abdu, P.A. and Sackey, A.K.B. (2009) Some Reproductive Disorders of the Indigenous Sheep and Goats in Zaria, Northern Nigeria. Nigerian Veterinary Journal, 30, 46-50. https://doi.org/10.4314/nvj.v30i1.65160

[54] Ahammad, S.Md., Rashedul, I., Rakesh, K.Y., Rupaly, A. and Jalal, U.A. (2015) Prevalence of Different Reproductive Disorders of Small Ruminants in Five Upazillas of Mymensingh District. Asian Journal of Medical and Biological Research, 1, 74-79. https://doi.org/10.3329/ajmbr.v1i1.25501

[55] Saberivand, A. and Haghighi, M. (2006) Acquired Reproductive Tract Abnormalities of Ewes in Northwest of Iran: An Abattoir Survey. Iranian Journal of Veterinary Research, 7, 14.

[56] Ramadan, A.A., Johnson, G.L. and Lewis, G.S. (1997) Regulation of Uterine Immune Function during the Estrous Cycle and in Response to Infectious Bacteria in Sheep. Journal of Animal Science, 75, 1621-1632. https://doi.org/10.2527/1997.7561621x

[57] Lewis, G.S. (2003) Steroidal Regulation of Uterine Resistance to Bacterial Infection in Livestock. Reproduction Biology and Endocrinology, 1, 117. https://doi.org/10.1186/1477-7827-1-117

[58] Ababneh, A.M. and Degefa, T. (2007) Bacteriological Findings and Hormonal Profiles in the Post-Partum Balady Goats. Reproductive Domestic Animal, 4, 12-16. https://doi.org/10.1111/j.1439-0531.2006.00638.x

[59] Hatipoglu, F., Ortatatli, M., Kiran, M.M., Erer, H. and Ciftci, M.K. (2002) An Abattoir Study of Genital Pathology in Cows: II. Uterus, Cervix and Vagina. Revue de Medicine Veterinaire, 153, 93-100.

[60] Jubb, K.V.F., Kennedy, P.C. and Palmer, N.C. (2007) Pathology of Domestic Animals. 5th Edition, Saunders Elsevier, Philadelphia, 2340 p.

[61] Abdul, S. and Khan, M.Z. (1988) Incidence and Pathology of Ovarian Diseases of Goat. Pakistan Veterinary Journal, 8, 18-21.

[62] Herenda, D. (1987) An Abattoir Survey of Reproductive Organ Abnormalities in Beef Heifers. Canadian Veterinary Journal, 28, 33-37.

[63] Farin, P.W. and Estill, C.T. (1993) Infertility Due to Abnormalities of the Ovaries in 
Cattle. Veterinary Clinical North America Food Animal Practice, 9, 291-308. https://doi.org/10.1016/S0749-0720(15)30647-2

[64] Khodakaram-Tafti, A. and Davari (2013) A Congenital and Acquired Abnormalities of Reproductive Tract of Non-Pregnant Ewes Slaughtered in Fars Province, Shiraz University, Iran. Iranian Journal of Veterinary Research, 14, 140-144.

[65] Regassaa, F., Mengeshaa, D., Dargiea, M. and Tolosab, T. (2009) Abattoir Evidence on Association between Uterine and Ovarian Abnormalities in Ethiopian Highland Ewes. Journal of Animal Science, 111, 384-390.

https://doi.org/10.1016/j.anireprosci.2008.03.020

[66] Arthur, G.H., Noakes, D.E. and Pearson, H. (1983) Veterinary Reproduction and Obstetrics (Theriogenology). 6th Edition, Balliere Tindal, 59, 444-456.

[67] Smith, K.C., Morgan, K.L. and Parkinson, T.J. (1996) Mating Patterns and Reproductive Wastage in Commercial Lowland Ewes in West Somerset. Veterinary Record, 139, 563-566.

[68] Jones, T.C., Hunt, D.R. and King, W.N. (1997) Veterinary Pathology. $6^{\text {th }}$ Edition, Lippincott Williams and Wilkins, Baltimore, 1149-1221.

[69] Smith, K.C., Long, S.E. and Parkinson, T.J. (1998) Abattoir Survey of Congenital Reproductive Abnormalities in Ewes. Veterinary Record, 143, 679-685.

[70] Martins, G., Figueira, L., Penna, B., Brandão, F., Varges, R., Vasconcelos, C. and Lilenbaum, W. (2009) Prevalence and Antimicrobial Susceptibility of Vaginal Bacteria from Ewes Treated with Progestin-Impregnated Intravaginal Sponges. Small Ruminant Research, 81, 182-184. https://doi.org/10.1016/j.smallrumres.2008.12.003 